Article

\title{
Freedom of Expression, Secularism and Defamation of Religion: The Case of Charlie Hebdo
}

\author{
Filimon Peonidis \\ Department of Philosophy, Aristotle University of Thessaloniki, GR 54124 Thessaloniki, Greece; \\ peonidis@edlit.auth.gr
}

Received: 1 August 2019; Accepted: 27 September 2019; Published: 1 October 2019

\begin{abstract}
I argue that under normal circumstances a state that is liberal and secular should not use its legal apparatus to suppress the publication of cartoons like those that triggered the deadly terrorist attack on the premises of Charlie Hebdo in 2015, if it is determined to abide by its core values. These values, which include religious neutrality, religious freedom, and unhindered freedom of criticism, imply that individual citizens are prima facie legally free to express their disapproval of particular religions or religious faith in general, through any non-violent means they consider appropriate, including parody and ridicule. This idea is open to various objections. Those focusing on the protection of religion as such can be easily dismissed, but the charge that defamation of religion causes offence to believers has to be taken seriously. Nevertheless, I defend the view that we need something stronger than taking offense to justifiably ban harsh religious criticism. In particular, I argue that, if the above sort of criticism prevents its recipients from exercising their basic rights or it incites third parties to engage in criminal activities against the above individuals, it should be subject to legal sanctions. However, this is not the case with the cartoons that appeared in Charlie Hebdo, since, as far as I can tell, no basic rights of French Muslims were violated, and no violent actions were committed against them as a result of their publication.
\end{abstract}

Keywords: defamation of religion; freedom of expression; offense; religious freedom; religious neutrality

\section{Introduction}

The assassination of many individuals during a terrorist attack on the premises of the French satirical magazine Charlie Hebdo in January 2015, which was triggered by the publication of a series of cartoons mocking the Prophet Muhammad, was wholeheartedly denounced in many parts of the world. ${ }^{1}$ Even if we grant that it was committed in the heat of anger, it was totally unjustifiable within the framework of the set of basic principles and rights that was recognized by the international community after the end of War World II. The value of human life has absolute priority, and none of its few legitimate and meticulously circumscribed exceptions can be applied to this case. However, absolute condemnation notwithstanding, some parallel considerations arose from this tragic series of events, which must be addressed in their own right. Some observers, moved by an impartiality requirement to take both sides in a controversy seriously, raised the question of whether advanced

1 Charlie Hebdo is a weekly "satirical, secular, political, and joyful" French magazine established in 1970. Its philosophy is that no person or value (political, religious, national, etc.), irrespective of its popularity or public significance, is not susceptible to harsh criticism, mocking, and ridicule. It has not hesitated to publish cartoons that disparage religious leaders or monotheistic religions. The content of the cartoons in which the Prophet is depicted naked or as saying things like "a hundred lashes if you don't die of laughter" leave no doubts about the blasphemous intentions of its cartoonists and in 2011 resulted in a victimless petrol bomb attack on its premises. The toll from the second attack in 2015 rose to twelve dead and four injured. For more information see https://charliehebdo.fr/ (accessed on 30 September 2019). 
democracies like France or Denmark should allow publications of this type. Shouldn't we take the idea of legally prohibiting the defamation of all religions seriously-not because of fear of reprisals from infuriated believers, but because there are overarching secular moral reasons to move in this direction? Does respect for believers imply their protection from exposure to such blasphemous material? Did the attackers have a moral point that they lost by resorting to wanton violence? The debate about the legality of the defamation of religion is by no means new (Keane 2008; Howard-Hassmann 2015), but thanks to certain sporadic incidents, such as the turmoil and the reverberations caused by Rushdie's Satanic Verses and the blasphemous cartoons published in Jyllands-Posten and Charlie Hebdo, it has reached a public far wider than the closed circle of constitutional lawyers and human rights experts.

I will argue in this essay that, if a liberal and secular state desires to abide by its basic tenets, under normal circumstances, ${ }^{2}$ it should condone the publication of cartoons such as those that appeared in Charlie Hebdo. I do not deny that there are many legal parameters in this issue that lie beyond my expertise, but I believe that a philosophical approach has much to offer. Thus, the discussion for the most part will retain a level of abstraction, and draw heavily on current discussions concerning freedom of expression and of religion. In addition, the debate will not be formulated in terms of a conflict between "western" and "non-western values", since, in my view, this way of seeing things is superficial, misguided, and leads to an argumentative deadlock. The idea of a secular and liberal society, which will be the starting point of my argument, may have been conceived primarily in the West, but nothing prevents it from finding fertile soil in other parts of the world.

\section{The Main Argument}

It could be maintained that the ban in question would be ineffective, given that any type of blasphemous material could be uploaded without cost on the internet, which should not be under state control for a variety of overarching reasons. This is a plausible view, but I would not like to make the trivial point that we ought not to prevent publications like Charlie Hebdo from reaching the section of the public to which they appeal, simply because this is not feasible. On the contrary, I would like to point out that there are substantial normative reasons proscribing this ban.

I start with an outline of two basic characteristics of a liberal and secular state, the validity of which I accept for my present purposes without discussion. First, this state recognizes the significance of religious worship for its citizens and grants them a corresponding freedom, without, however, promoting, privileging, being associated or identified with a particular religion. Second, it acknowledges that no set of ideas, convictions, or beliefs is immune to criticism, no matter how popular, sacred, or entrenched it is. It maintains that the unhindered expression of all views and especially of the most challenging, unpleasant, or controversial ones is necessary for the proper functioning of democratic self-government and the creation of a vivid and healthy intellectual atmosphere to everyone's benefit. This implies that the state protects at least prima facie the free expression of views that are likely to trigger vehement reactions from segments of the public on the grounds that they are considered mistaken or contrary to their convictions. The views everyone wants to hear do not need any kind of legal protection.

The right to criticize religion derives from these two defining normative tenets of the secular and liberal polity. If we assume that the state endorses religious neutrality and puts a high premium on religious freedom and critical discourse, then it follows that all citizens are free to pursue their own faith through non-violent means (or live without any religious faith whatsoever). This pursuit includes the freedom to criticize other religions which are in principle incongruent with their one and only true religion. This does not mean that a believer cannot tolerate the existence of other religions and seek

2 By insisting on normal circumstances, I would like to exclude cases where a state of emergency has been declared, certain articles of the constitution have been suspended, or religious factions threaten to plunge the country into a civil war. I also take for granted that the above state is democratic and multi-religious. 
some modus vivendi with people of different creeds, but this stance is not undergirded by any type of religious relativism or syncretism. On the contrary, it might be dictated by an internal prescription-as is the case with Islam's approach to the religions of the Bible-or by purely practical considerations. Furthermore, the freedom to live the life of an atheist entails the freedom to criticize the religious phenomenon in general for epistemic, moral, or pragmatic reasons. No one can make a good case for atheism if she is unable to show what's wrong with belief in God. Finally, it goes without saying that criticism of religion can be expressed through all the conventional means used in our societies to voice our disapproval of something, including symbolic protest and the publication of images.

This position could be met with various possible objections that need to be seriously considered. Someone might argue that the most sacred dogmas of a religion should be immune to criticism, whereas this should not apply to their more peripheral elements. However, this distinction is untenable. As the recent bitter debates concerning the way Muslim women should appear in French public schools have shown, dress codes required by religions are for the believer's self-image (at least) equally important to the most abstract and intractable theological dogmas. In addition, any attempt of the state to determine what is more or less significant within the confines of a specific religion can be envisaged as a violation of the religious neutrality it professes.

Another objector could point out that we need to draw a distinction between "decent" and "indecent" forms of religious criticism. The latter, which includes blasphemy, here conceived as the explicit and outright parodying, mocking, and ridiculing of religion, should be legally banned, whereas the former, which includes the formulation of serious theological objections, should be tolerated. The cartoons of Charlie Hebdo were blasphemous in that sense; therefore, their publication should have been suppressed. The second premise of the argument is undeniable, but the real question is whether we are justified in drawing such a normatively tainted distinction within a framework that champions critical discourse.

It could be retorted that for certain religions this distinction is inappropriate. One does not need to be an expert in the history of Christianity to realize that many people lost their lives in rather tragic circumstances because they offered serious theological arguments challenging the established orthodoxy. However, I will not pursue this line further, since my approach is philosophical and not inter-religious or intra-religious.

What matters most in this debate is to realize that parody and ridicule are (a) forms of extreme and harsh criticism and (b) forms of criticism that cannot be replaced by other milder forms of criticism without a loss in the meaning they would like to convey to the audience they address.

Starting with the first point, it is evident that they cannot be regarded as types of constructive criticism, since they aim at a total deconstruction or undermining of their object and urge the public to start seeing it in an utterly disparaging manner. Thus, given the high degree of coherence and homogeneity of the belief-set comprising a religious creed and the heavy and paternalistic demands religions make on believers - in fact, the most widespread religions seek an absolute control over many aspects of their way of living, thinking, and acting-it should not come as a surprise that religious criticism often ends up with the total rejection ${ }^{3}$ of a particular religion or of religious faith in general. ${ }^{4}$ An argument to the effect that one should be "Christian or Buddhist to a certain extent" would not make much sense for most individuals, religious or not.

Moreover, by taking their object out of the context in which it is usually presented, parody and ridicule offer "a destabilization of meaning through allusion and humour" (Plamer 2005, p. 81) and sometimes through foul language and obscenity. There is in them a unity of form and content that cannot

3 For this reason, an effective agreement among the representatives of major religions to refrain from criticizing each others' beliefs and practices-i.e., the establishment of a minimal inter-religious code of ethics to reduce religious conflicts-seems at present highly unlikely.

4 To these one should add the cases of people who believe that their lives were destroyed by blindly and unconditionally following the dictates of a religion with which they had grown disenchanted. 
be disrupted without betraying the aims of the parodist or the satirist. As Ronald Dworkin (2006, p. 44) put it in respect to ridicule:

Ridicule is a distinct kind of expression; its substance cannot be repackaged in a less offensive rhetorical form without expressing something very different from what was intended. That is why cartoons and other forms of political ridicule have for centuries, even when illegal, been among the most important weapons of both noble and wicked political movements.

To give an historical example, one can be very critical of the underground pornographic publications that appeared in France before the outbreak of the French Revolution, in which queen Marie-Antoinette was the protagonist (Hunt 1984). However, one cannot say that the popular outcry for her alleged debauchery could have been expressed with an equal force in a less coarse manner. Innuendos, for instance, could not have conveyed the sense of indignation against her, which undoubtedly had an impact on the series of events that sealed her fate a few years later.

Hence, if a secular and liberal polity endorses this distinction between decent and indecent forms of religious criticism and legislates accordingly, it would give its citizens the following message: do not be too harsh with religion unless you would like to face legal procedures. However, such a policy would bestow on religions a privileged status, which is incompatible with the religious neutrality it professes and would outlaw certain irreplaceable forms of criticism in contravention to the emphasis it assigns to critical discourse.

Perhaps a critic could try a different route by arguing that constant defamation of religions will eventually lead to their extinction. However, religions are not engendered species. As such, they are not entitled to any protection. If a religion no longer appears to be a real option, it has an interest only for the historian or the anthropologist, and there is nothing to be lamented over this development. The situation would be different if it were expected that from the conflict of religions some new universally accepted religious doctrine would emerge, as might be the case with other competing ideas. This is, however, very unlikely to happen in the modern world. The overwhelming majority of believers are appalled by the idea of an interreligious dialogue in search of a new common faith. On the contrary, what need our protection are the various human artifacts created for religious purposes, such as temples, works of art, or manuscripts, because of their high cultural and historical value. In addition, we must ensure that people's freedom to worship any religion they like, if they are attracted to religions, is not infringed. It is evident that this worship is an essential part of their well-being and offers them meaning in their lives and a distinct identity. Yet, this is a different issue. In the words of a human rights expert (Bielefeldt 2013, p. 42):

[T] he idea of protecting the honor of religions is clearly at variance with the human rights approach, which institutionalizes due respect for the dignity and freedom of human beings rather than protecting religion as such. Thus, it would be a great misunderstanding to somehow associate freedom of religion or belief with the fight against defamation of religion. ${ }^{5}$

Nevertheless, if one cannot criticize the toleration of the defamation of religion by appealing to the damage it does to religions viewed as a coherent set of doctrines and beliefs that may fall into oblivion, one can enquire if it has any negative effects on believers. Along these lines, a critical argument can take the following form: given that religion is of paramount value to a believer and an essential part of her identity and self-image, the public expression of such contempt for it constitutes a severely offensive experience for her. Moreover, the damage done cannot be undone by issuing a retraction, as in the case of a false rumor that threatens her reputation. The remedy for sacrilege is not to show that the sacrilegious person is wrong but to inflict on her some sort of punishment. Therefore, defamation of religion should not be allowed at all, and transgressors like the Charlie Hebdo journalists should face 
legal penalties. It has to be pointed out that one does not have to be religious to recognize the force of this argument; it suffices to have an empathetic understanding of how significant religion is for her fellow men.

A liberal and secular polity cannot but recognize that defamation of religion can cause serious offense. The question is whether this is sufficient ground for legislating against it. This inquiry unavoidably leads to an examination of the notion of offense.

According to the seminal analysis of Feinberg (1992); and for a full account Feinberg (1985), "I am offended in the narrow sense (or "take offense") when:

(a) I suffer a disliked state;

(b) I attribute the state to the wrongful conduct of another; and

(c) I resent the other for causing me to be in the state."

Although it cannot be denied that offense is a form of harm in the sense of producing an adverse effect on someone's interest and, in particular, on her interest not to experience unpleasant and painful mental states, it is considered less serious than other forms of harm, such as taking someone's life or unlawfully depriving her of her freedom. This is because there is a partially subjective element in taking offence that is absent in other forms of harm one can suffer. It is not unusual for two persons to react differently to the same utterance or for the same person to be offended by a statement that, in a different context, would had passed unnoticed by her. The conditionally harmful character of offense is explained by the fact that the seriousness of the damage afflicted can be mitigated or even remedied by the mental efforts of its target, something that is out of the question, say, in the case of the victim of a shooting.

As Irvine (2013) has pointed out, there is a variety of strategies at an individual's disposal to counteract the adverse effects of offense. These include retaliatory insults, showing contempt for the offender through acts and omissions, or "defusing" her by showing her the fallacious reasoning, the misconceptions, and the character flaws pertaining to her conduct. Irvin's own sympathies lie with a stoic attitude of passivity and non-response, which he dubs "insult pacifism". This means saying nothing when insulted or resorting to self-deprecating humor. I understand that insult pacifism may not find many friendly ears, but one does not need to endorse it to realize that there are many ways to deal successfully with offence by one's own means without resorting to violence or asking a stronger third party to intervene on her behalf.

This attitude is not unknown to certain religions, such as Christianity. The idea that the blasphemous person is in error and has to be treated accordingly is encapsulated in Jesus' words: "Father, forgive them, for they do not know what they are doing" (Luke 23, 34). In addition, believers can always claim that blasphemy is inconsequential, since their faith is destined to emerge triumphant in the end.

This is why a liberal and secular polity is rather reluctant to suppress defamation of religion on the ground that is offensive to believers. It does not want to downplay the disliked states and the resentment certain believers experience, but it also realizes that sometimes the mere existence of infidels is an offense in the eyes of certain fundamentalists and fanatics. In addition, it prefers to let the citizens themselves deal with blasphemy through their own non-violent means, rather than suppressing a highly prized freedom. The only legal protection it is willing to offer to everyone against offence caused by blasphemy is to prevent the relevant material from easily reaching those who do not want to have access to it. If blasphemous material can be found only in publications one has to seek, at indoor art exhibitions, theaters, or on special Internet sites, and sufficient warnings are given about its nature, in such cases believers could avoid it without any considerable cost.

\section{Possible Exceptions}

The previous theoretical arguments for the penalization of religious criticism have been found wanting, although the discussion was far from complete. However, the complexity of the issues 
involved and the variety of the relevant practical cases that have arisen (and may arise in the future) call for an extremely cautious and non-dogmatic approach. I will refer to three separate cases.

The first refers to what Garton Ash (2016) called the "assassin's veto". In recent years, certain radical groups have threatened to kill those involved in publications that cause offense to the Muslim world, and the attack on Charlie Hebdo and other incidents showed that they were not joking. Should a secular and liberal state yield to such claims and suppress these publications in an effort to save as many lives as possible? This would make a democratic government hostage to terrorist demands, some of which may come from citizens of foreign and distant states, thus allowing extreme and murderous groups to impose their will on legislative matters. There is also the question of who will judge what is offensive and to whom. Should the authorities assign this task to local religious leaders? Should atheists have a say in this issue? Generally speaking, the imposition of such a ban would compromise freedom of expression and religious freedom ${ }^{6}$ and may prepare the ground for further concessions. Moreover, the government would appear to admit either that religious people in general are "incapable of reasonable self-restraint" or that "such self-restraint is something that should never be asked of them" (Appiah 2012, p. 168). The first attitude would be demeaning to them, and the second would amount to unjustifiable preferential treatment. Thus, a secular and liberal polity should not accept the assassin's veto but rather use its resources to protect those threatened by fundamentalist groups or foreign religious authorities.

However, it cannot be denied that, on certain occasions, individual editors and publishers face a real moral dilemma, even if the authorities are eager to stand by them. Given the fact that we can think of situations where no guarantees can be given that third parties will not suffer any harm in retaliation for the publication or republication of blasphemous material, editors and publishers "should ask themselves whether their struggle to express outrageous ideas freely justifies putting other people's lives at risk. It is one thing to be willing to pay a price for your own conduct. It is quite another to expect others to chip in for a cause that they do not endorse as strongly" as the editors and publishers do (Cohen-Almagor 2016). Of course those who pull the trigger are the terrorists, but it cannot be said that editors and publishers bear no moral responsibility at all for the consequences of their actions. Especially in cases where it is clear that multiple fatalities will occur, including people who are not directly involved in the publishing process, a decision not to publish is praiseworthy. In addition, freedom of expression is not incompatible with self-restraint. From the fact that utterance $\mathrm{x}$ is protected by law, it does not follow that I have an absolute duty to utter $\mathrm{x}$. I might choose to remain silent for a variety of reasons related to the consequences of uttering $x$, including moral ones. ${ }^{7}$ It is one thing is to have a right but another thing to decide when to exercise it (Haworth 2015).

In the second case, the believers whose religion is defamed are not only offended, but also have their basic rights violated because of this defamation. Consider the following example. Some Christian students use the Charlie Hebdo cartoons, which they post all over their school to harass a small minority of Muslim students. As a result, the latter refuse to go to school, to maintain their sense of dignity, a decision that jeopardizes their prospects for a good life. This is a clear violation of their right to education. The state has an obligation to secure equally good educational conditions for everyone. In cases like this, the school authorities should intervene and try to improve the atmosphere in the school through various means, including the prohibition of the circulation of the above cartoons. Along similar lines, we can think of a more general case, where the wider public displaying an endorsement of similar defamatory material will force members of a religious minority to move to other places to save themselves the embarrassment and the humiliation. This amounts to an onslaught of their

6 As Garton Ash (2016, p. 130) put it "[t]he generic evil underlying so many illegitimate abuses of and curbs on free speech turns out to be the real or attributed threat to violence".

7 On the issue of self-restraint, see Holmes (1988) and Festenstein (2018). 
basic rights and justifies the suppression of the material in question. ${ }^{8}$ It should be noted, however, that that this would be an extraordinary measure targeting the specific publication that brought about this outrageous state of affairs. Other things being equal, there should be no general ban on the defamation of religion. Returning now to Charlie Hebdo, to the best of my knowledge, I cannot claim that it contributed to the violation of any basic right of French Muslims, given its limited circulation and popularity. Before the 2015 attacks, almost nobody "était Charlie Hebdo".

Finally, in the third case, the defamation of religion is accompanied by an incitement addressed to third parties to take violent and harmful action against a specific group of believers. In these cases, the attack on a particular religion is calculated not only to cultivate hate against its supporters, but also to make this emotion the driving force for a variety of unlawful assaults on them. The Jewish populations, which were often the victims of this tactic, come easily to mind. However, from a free speech perspective, it is clear that incitement to crime does not enjoy any legal protection. This has been pointed out by John Stuart Mill in On Liberty:

An opinion that corn-dealers are starvers of the poor, or that private property is robbery, ought to be unmolested when simply circulated through the press, but may justly incur punishment when delivered orally to an excited mob assembled before the house of a corn-dealer, or when handed about among the same mob in the form of a placard. (Mill 1977, p. 260; see also Peonidis 2008)

In the 20th century, this has also become official legal doctrine after the famous ruling of the U.S. Supreme Court in Brandenburg vs. Ohio 395 U.S. 444 (Supreme Court of the United States 1969):

Freedoms of speech and press do not permit a State to forbid advocacy of the use of force or of law violation except where such advocacy is directed to inciting or producing imminent lawless action and is likely to incite or produce such action.

The idea is that speakers should be criminally liable if they intended to harm their targets through third parties and it can be established that, under the circumstances, incitement could easily lead to unlawful action. ${ }^{9}$ However, in the case of the Charlie Hebdo cartoons, there is not even a shred of evidence that their authors were envisaging them as a battle cry for looting the houses of French Muslims. The previous publication of cartoons targeting other religions, including Christianity and Judaism, bears testimony to the fact that their (rather unusual) intention was only to deride other people's most sacred beliefs.

\section{Conclusions}

To conclude, as a matter of principle, a liberal and secular state should not ban publications like Charlie Hebdo, which are engaged in defaming particular religions or religion in general. This commitment is not unqualified but the cartoons that appeared in this magazine do not fall within the scope of legitimate exceptions. Thus, the question posed in the title of this essay has to be answered in the negative. It follows from this that all citizens who share the basic principles of this polity and disagree with the content of these publications have to come to terms with the fact that the only legitimate way to express their opposition is through criticism, condemnation, or indifference.

Funding: This work received no external funding.

Acknowledgments: The author would like to thank two anonymous referees for their valuable suggestions.

Conflicts of Interest: The author declares no conflict of interests.

One could envisage a rare situation where a wide defamatory campaign is launched against a socially disadvantaged religious majority by an aggressive and powerful religious minority. In this case also the state should interfere and ban the defamatory material to protect the rights of those belonging to the above majority.

9 See among many others Weinstein (2009). 


\section{References}

Appiah, Kwame Anthony. 2012. What's Wrong with the Defamation of Religion? In The Content and Context of Hate Speech. Edited by Michael Herz and Peter Molnar. Cambridge: Cambridge University Press, pp. 164-82.

Bielefeldt, Heiner. 2013. Misperceptions of Freedom of Religion or Belief. Human Rights Quarterly 35: 33-68. [CrossRef]

Cohen-Almagor, Raphael. 2016. The Charlie-Hebdo Affair: Between Speech and Terror. The Critique's Great War Series Part II: Charlie Hebdo, Free Speech \& Religious Violence. Available online: https://hullrepository.worktribe.com/output/440154/the-charlie-hebdo-affair-between-speech-and-terror (accessed on 30 September 2019).

Dworkin, Ronald. 2006. The Right to Ridicule. The New York Review of Books 53: 44.

Feinberg, Joel. 1985. Offense to Others. Oxford: Oxford University Press.

Feinberg, Joel. 1992. Harm and Offense. In Encyclopedia of Ethics. Edited by Lawrence C. Becker and Charlotte B. Becker. New York: Garland, pp. 437-40.

Festenstein, Matthew. 2018. Self-censorship for Democrats. European Journal of Political Theory 17: 324-42. [CrossRef] Garton Ash, Timothy. 2016. Free Speech: Ten Principles for a Connected World. London: Atlantic Books.

Haworth, Alan. 2015. On Charlie Hebdo and Free Speech. The Philosopher's Magazine 69: 17-22. [CrossRef]

Holmes, Stephen. 1988. Gag Rules or the Politics of Omission. In Constitutionalism and Democracy. Edited by Jon Elster and Rune Slagstad. Cambridge: Cambridge University Press, pp. 19-58.

Howard-Hassmann, Rhoda E. 2015. The Charlie Hebdo Murders and Freedom of Speech. The Indonesian Journal of International and Comparative Law 2: 467-80.

Hunt, Lynn. 1984. Politics, Culture, and Class in the French Revolution. Berkeley: University of California Press.

Irvine, William Braxton. 2013. A Slap in the Face: Why Insults Hurt-And Why They Shouldn't. Oxford: Oxford University Press.

Jahangir, Asma, and Doudou Diène. 2006. Report of the Special Rapporteur on Freedom of Religion or Belief, Asma Jahangir, and the Special Rapporteur on Contemporary Forms of Racism, Racial Discrimination, Xenophobia and Related Intolerance, Doudou Diène, Further to Human Rights Council Decision 1/107 on Incitement to Racial and Religious Hatred and the Promotion of Tolerance. UN Doc. A/HRC/2/3. September 20. Available online: https://undocs.org/en/A/HRC/2/3 (accessed on 30 September 2019).

Keane, David. 2008. Cartoon Violence and Freedom of Expression. Human Rights Quarterly 30: 845-75. [CrossRef] Mill, John Stuart. 1977. On Liberty. In Essays on Politics and Society. Edited by J. M. Robson and Alexander Brady. Toronto: University of Toronto Press. First published 1859.

Peonidis, Filimon. 2008. A Note on Mill's Early Theory of Free Speech. Australesian Journal of Legal Philosophy 33: 60-65.

Plamer, Jerry. 2005. Parody and Decorum: Permissions to Mock. In Beyond a Joke: The Limits of Humour. Edited by Sharon Lockyear and Michael Pickering. Houndmills: Palgrave Macmillan, pp. 79-95.

Supreme Court of the United States. 1969. Brandenburg vs. Ohio. 395 U.S. 444 1969. Available online: https://www.loc.gov/item/usrep395444/ (accessed on 30 September 2019).

Weinstein, James. 2009. An Overview of American Free Speech Doctrine and its Application to Extreme Speech. In Extreme Speech and Democracy. Edited by Ivan Hare and James Weinstein. Oxford: Oxford University Press, pp. 81-91.

(C) 2019 by the author. Licensee MDPI, Basel, Switzerland. This article is an open access article distributed under the terms and conditions of the Creative Commons Attribution (CC BY) license (http://creativecommons.org/licenses/by/4.0/). 